\title{
Baicalein suppresses the androgen receptor (AR)-mediated prostate cancer progression via inhibiting the AR N-C dimerization and AR-coactivators interaction
}

\author{
Defeng $\mathrm{Xu}^{1}{ }^{1}$, Qiulu Chen ${ }^{1}$, Yalin Liu ${ }^{1}$ and Xingqiao Wen ${ }^{2}$ \\ ${ }^{1}$ School of Pharmaceutical Engineering and Life Sciences, Changzhou University, Changzhou, Jiangsu 213164, P.R. China \\ ${ }^{2}$ Department of Urology, Shenzhen Hospital of Southern Medical University, Shenzhen, Guangdong 518100, P.R. China \\ Correspondence to: Defeng Xu, email: markxu@cczu.edu.cn \\ Xingqiao Wen, email: $18922102731 @ q q . c o m$ \\ Keywords: anti-androgen; baicalein; flavonoids; prostate cancer; androgen receptor \\ Received: March 28, $2017 \quad$ Accepted: June 28, $2017 \quad$ Published: November 06, 2017 \\ Copyright: Xu et al. This is an open-access article distributed under the terms of the Creative Commons Attribution License 3.0 (CC \\ BY 3.0), which permits unrestricted use, distribution, and reproduction in any medium, provided the original author and source are \\ credited.
}

\section{ABSTRACT}

Background: Androgen receptor (AR) plays a critical role in prostate cancer (PCa) development and progression. Androgen deprivation therapy with antiandrogens to reduce androgen biosynthesis or prevent androgens from binding to AR are widely used to suppress AR-mediated PCa growth. However, most of ADT may eventually fail with development of the castration resistance after 12-24 months. Here we found that a natural product baicalein can effectively suppress the PCa progression via targeting the androgen-induced AR transactivation with little effect to AR protein expression.

Methods: PCa cells including LNCaP, CWR22Rv1, C4-2, PC-3, and DU145, were treated with baicalein and luciferase assay was used to evaluate their effect on the AR transactivation. Cell growth and IC $_{50}$ were determined by MTT assay after 48 hrs treatment. RT-PCR was used to evaluate the mRNA levels of AR target genes including PSA, TMPRSS2, and TMEPA1. Western blot was used to determine AR and PSA protein expression.

Results: The natural product of baicalein can selectively inhibit AR transactivation with little effect on the other nuclear receptors, including ERo, and GR. At a low concentration, $2.5 \mu \mathrm{M}$ of baicalein effectively suppresses the growth of AR-positive PCa cells, and has little effect on AR-negative PCa cells. Mechanism dissection suggest that baicalein can suppress AR target genes (PSA, TMPRSS2, and TMEPA1) expression in both androgen responsive LNCaP cells and castration resistant CWR22Rv1 cells, that may involve the inhibiting the AR N/C dimerization and AR-coactivators interaction.

Conclusions: Baicalein may be developed as an effective anti-AR therapy via its ability to inhibit AR transactivation and AR-mediated PCa cell growth.

\section{INTRODUCTION}

Prostate cancer (PCa) is the second leading cause of cancer death among American men. In 2015, approximately 228,800 men were diagnosed with $\mathrm{PCa}$, and 27,540 men were expected to die from this disease in the United States [1]. The lifetime risk for a U.S. male to develop PCa is about 1 in 6 , although the risk of dying from $\mathrm{PCa}$ is only 1 in 35 [2]. Use of androgen deprivation therapy (ADT) as a therapeutic modality for PCa patients didn't start until 1941 when Huggins and Hodges treated advanced PCa patients via ADT with surgical castration [3]. Since then, ADT has been proven to be as an effective treatment for patients with advanced PCa.

ADT aims to reduce the biosynthesis of androgens and/or prevent from androgen binding to androgen receptor (AR) [4-6]. However, most patients relapse 
after an initial response to ADT, and eventually develop the castration-resistant prostate cancer (CRPC) [7, 8]. Mechanism dissection indicated that the failure of ADT might involve the inability to further suppress the ARmediated PCa progression, and many of ADT might lead to increase the expression of AR even the androgen concentration was maintained at the castration level [9, 10]. Importantly, recent studies also suggested that nonandrogens including various growth factors, cytokines, protein kinases or interacting with selective coactivators could also transactivate AR in an androgen-independent mechanism [11]. Targeting AR, instead of targeting the androgens with antiandrogens, to better suppress the ARmediated CRPC progression is urgently needed $[12,13]$.

Flavonoids are widely used in the Chinese herbal medicines, and epidemiological studies indicated that an increased intake of dietary flavonoids might be associated with a decreased risk of selective cancers [14-16]. Baicalein (5,6,7-trihydroxyflavone) is a bioactive flavonoid originally isolated from the root of Scutellaria baicalensis Georgi [17], that has been widely used to treat with various inflammatory diseases including cardiovascular diseases, chronic hepatitis [1821] and some selective cancers including breast cancer, hepatocellular carcinoma, leukemia, and colon cancer [22-26].

Here we investigated the ability of baicalein to regulate $A R$ transactivation, and results revealed that baicalein could inhibit the growth of PCa AR-positive cells including LNCaP, C4-2 and CWR22Rv1 cells, with little effect on the AR-negative PC-3 and DU145 cells. Mechanism dissection indicated that baicalein could effectively inhibit AR activity via inhibiting the AR dimerization and AR-coregulation complex formation.

\section{RESULTS}

\section{Baicalein specifically inhibits the DHT-mediated AR transactivation, but not the ER, PR, and GR-mediated transactivation}

Early studies indicated Baicalein (see its structure in Figure 1A) might suppress several inflammatory diseases and some selective cancers [18-26]. Its potential effect to the PCa progression via impacts on the AR dimerization and AR transactivation, however, remains unclear. We first examined its effect on the AR transactivation via assaying the luciferase activity with MMTV containing the androgen-response-element (ARE) in the HEK 293 cells, and results revealed that androgen-DHT induced AR transactivation was suppressed but by antiandrogenHF (Figure 1B). Interestingly, adding baicalein also led to suppress the DHT-induced AR transactivation (Figure 1B). Similar results were also obtained when we replaced HEK 293 cells with androgen-sensitive PCa LNCaP cells and CRPC CWR22Rv1 cells, showing $1 \mathrm{nM}$ DHT- induced AR transactivation was suppressed by baicalein in a dose-dependent manner (Figure 1C-1D). Consistently, the AR activity induced by an alternative ligand, R1881, can also be inhibited by baicalein treatment (Figure 1E, $1 F)$. In contrast, we found baicalein failed to suppress the $10 \mathrm{nM}$ estrogen (E2)-induced ER $\alpha$ transactivation (Figure 1G) and $10 \mathrm{nM}$ glucocorticoid-Dex-induced GR transactivation (Figure $1 \mathrm{H}$ ).

We further studied the effects of baicalein on the other inducers including D5-androstenediol (Adiol) or E2 to the AR transactivation [36], and results revealed that 5 $\mu \mathrm{M}$ baicalein could effectively inhibit the Adiol- or E2mediated transactivation of wild type (Wt) AR and mutant AR in HEK 293 cells (Figure 1I-1J).

\section{Baicalein treatment inhibits the DHT-induced growth of AR-positive, but not the AR-negative PCa cells}

To further study the consequences of baicaleinsuppressed AR transactivation, we investigated its impact on the AR-mediated PCa cell growth. The results from MTT growth assay suggested that the $2.5 \mu \mathrm{M}$ baicalein could effectively reduce DHT-induced cell growth in androgen-sensitive LNCaP cells by $56.5 \%$, as well as CRPC CWR22Rv1 cells by $48.5 \%$ and C4-2 cells by $51.5 \%$ (Figure 2A-2C). In contrast, baicalein has little effect on the growth of PCa AR-negative cells including PC-3 and DU145 cells (Figure 2D-2E).

The half maximal inhibitory concentration (IC50), a measure of the effectiveness of a compound in inhibiting biological or biochemical functions [37], for baicalein on the PCa cells in the presence of DHT in LNCaP, CWR22Rv1, C4-2, PC-3, and DU145 were $8.8 \pm 1.4 \mu \mathrm{M}$, $21.8 \pm 2.5 \mu \mathrm{M}, 16.8 \pm 2.0 \mu \mathrm{M}, 27.8 \pm 3.0 \mu \mathrm{M}$ and $35.0 \pm 3.5$ $\mu \mathrm{M}$, respectively (Figure $3 \mathrm{~A}-3 \mathrm{E}$ ). In the absence of DHT, the $\mathrm{IC}_{50}$ concentrations for baicalein in $\mathrm{LNCaP}$, CWR22Rv1, PC-3 and DU145 were $6.2 \pm 1.3 \mu \mathrm{M}, 21.3 \pm 2.5$ $\mu \mathrm{M}, \quad 15.2 \pm 2.0 \mu \mathrm{M}, 27.3 \pm 3.0 \mu \mathrm{M}$ and $33.8 \pm 3.5 \mu \mathrm{M}$, respectively (Figure 3A-3E). Although it seems the IC50 values (Figure 3 ) for the various PCa cells do not correlate with the levels of growth inhibition (Figure 2), there is no conflict between the presented Figure 2 and Figure 3 data. One difference is the experimental condition: the IC50 of Figure 3 was determined after 48 hours ( 2 days) of compound treatment and the Figure 2 baicalein growth inhibition data were determined by continual treatment of 2, 4, and 6 days. The determination of IC50 values after 2 days treatment is a generally agreed upon protocol.

Together, results from Figure 2-3 suggest that baicalein may suppress the PCa AR-positive cell growth. This conclusion is further supported by the results from qPCR assay showing baicalein can suppress the $1 \mathrm{nM}$ DHTinduced expressions of several AR target genes including PSA, TMPRSS2, and TMEPA1 in a dose-dependent manner in LNCaP and CWR22Rv1 cells (Figure 4). 
<smiles>O=c1cc(-c2ccccc2)oc2cc(O)c(O)c(O)c12</smiles>
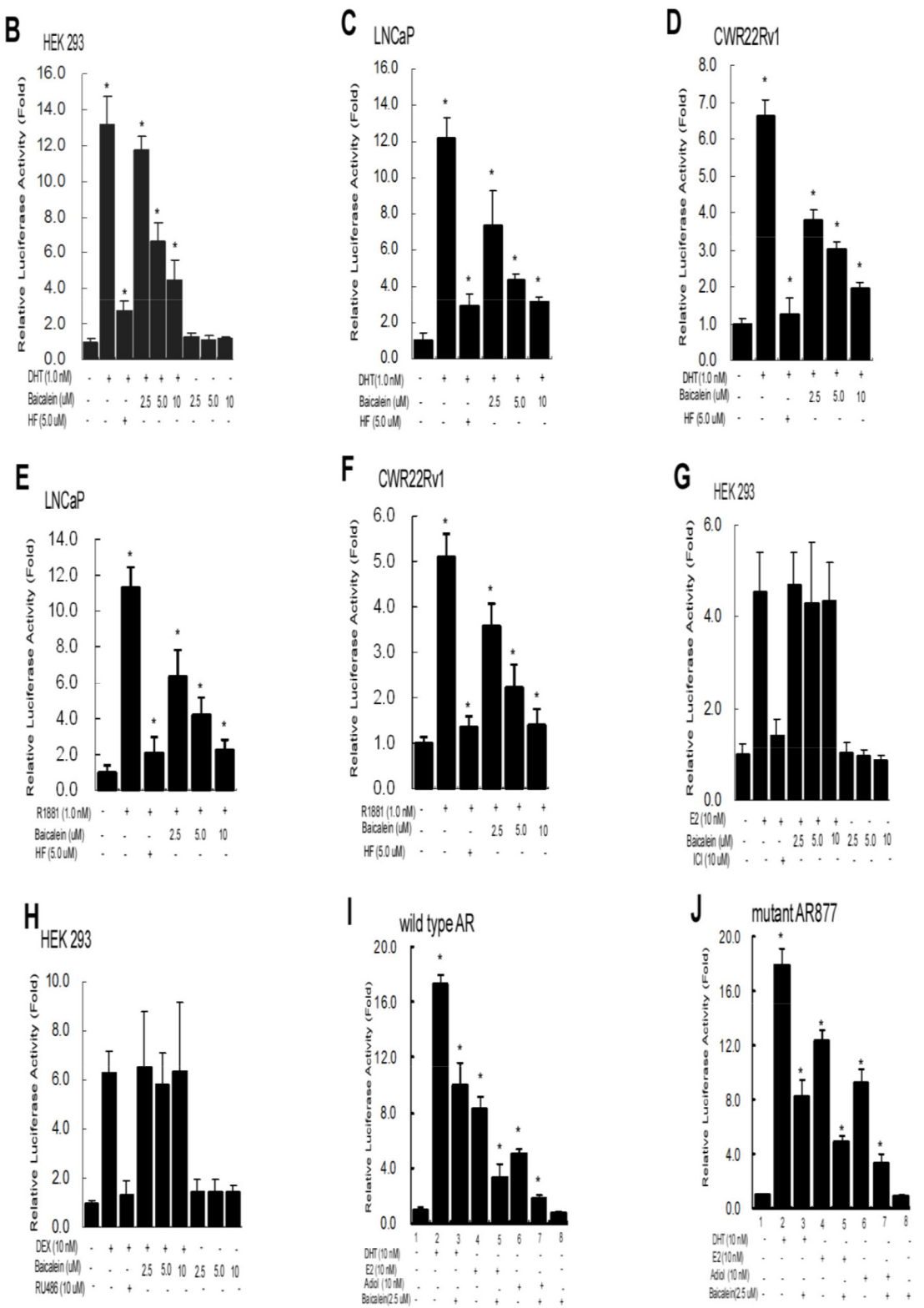

Figure 1: Baicalein selectively inhibits DHT-mediated AR transactivation, but not the ERo, PR, or GR activity. (A) Chemical structure of Baicalein. (B) Baicalein inhibits the androgen-induced transcriptional activity of wild type AR in HEK 293 cells. (C) Baicalein inhibits the DHT-induced AR transcriptional activity of a gain-of-function mutant AR (T877A) in prostate cancer LNCaP cells. (D) Baicalein inhibits the DHT-induced AR transcriptional activity in CWR22Rv1 cells. (E) Baicalein inhibits the R1881-induced AR transcriptional activity of a gain-of-function mutant AR (T877A) in prostate cancer LNCaP cells. (F) Baicalein inhibits the R1881-induced AR transcriptional activity in CWR22Rv1 cells. (G-H) Baicalein shows no effect on the transcriptional activities of estrogen-induced ER $\alpha$ and DEX-induced GR in HEK 293 cells. MMTV-Luc or ERE-Luc activities were determined. (I-J) Baicalein inhibits the E2 and Adiolinduced full length AR transactivation. AR-regulated MMTV-Luc reporter gene was activated in the presence of $10 \mathrm{nM}$ DHT, E2, or Adiol in HEK293 cells (lanes 2, 4, 6). $5 \mu \mathrm{M}$ Baicalein could effectively inhibit the DHT, E2, and Adiol-stimulated AR activity (lanes 3, 5, 7). The solvent (DMSO) treated AR-baseline transcriptional activity was counted as 1 fold (lane 1). Data were averaged from three independent experiments. 

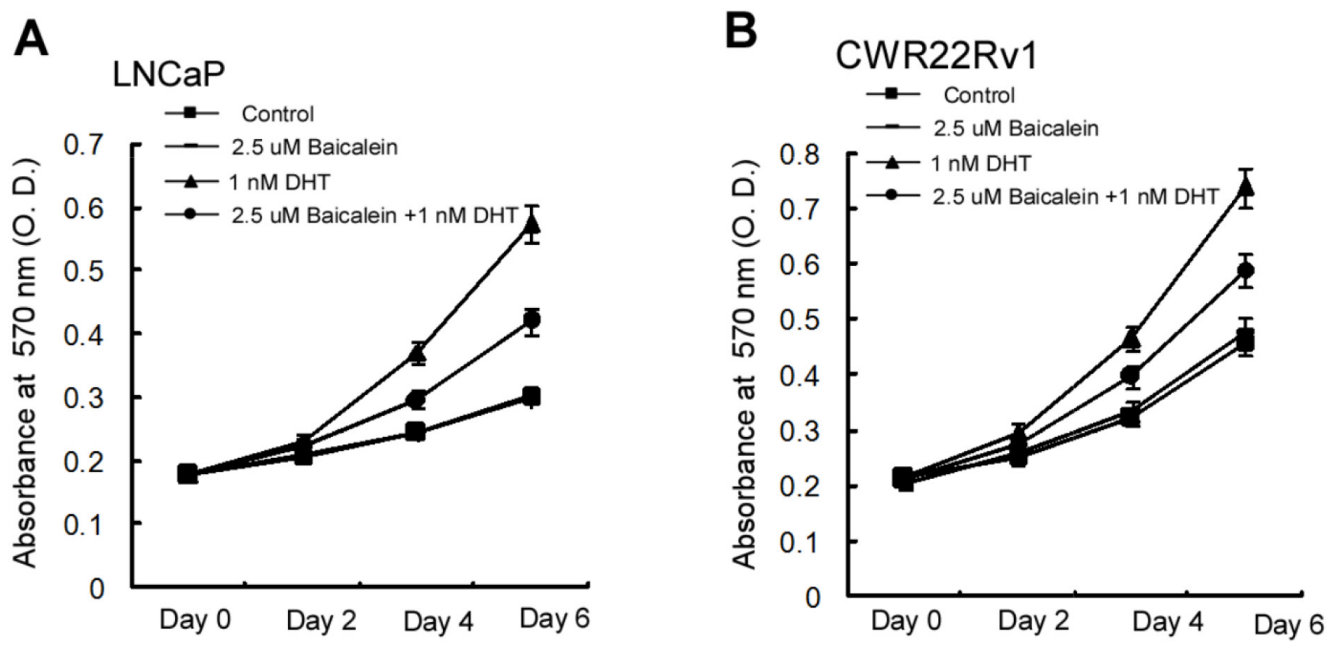

\section{C $\mathrm{C} 4-2$}
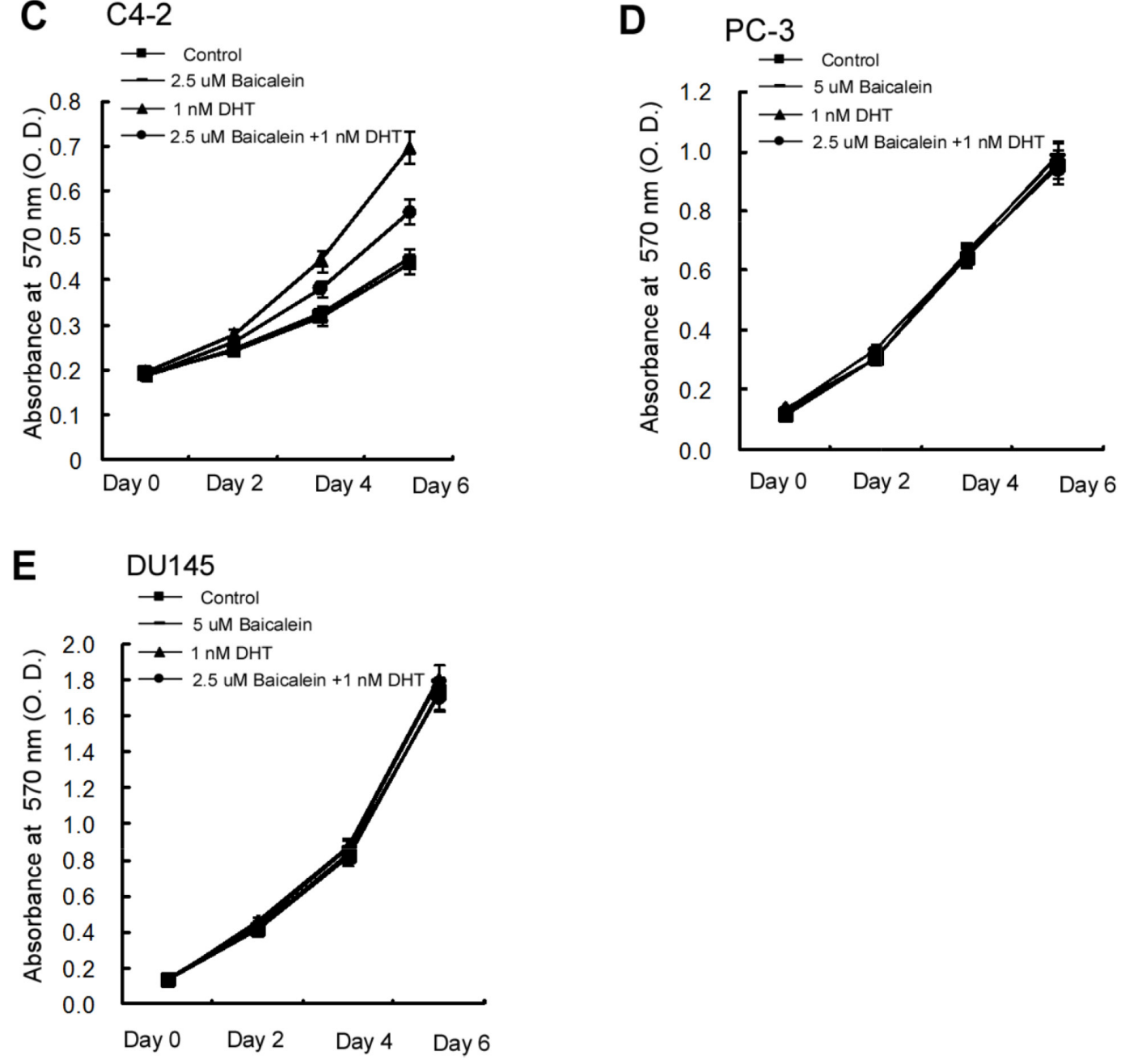

Figure 2: Differential growth inhibition effects of Baicalein on different prostate cells. Cells were treated with dimethyl sulphoxide and baicalein $(5 \mu \mathrm{M})$ in the absence or presence of $1.0 \mathrm{nM}$ DHT. Media with indicated treatments were refreshed every 2 days for a total of 7 days. (A) Baicalein inhibits the DHT-induced growth of LNCaP cells (B) Baicalein inhibits the DHT-induced growth of CWR22Rv1 cells. (C) Baicalein inhibits the DHT-induced growth of C4-2 cells. (D) No significant effect of baicalein on the growth of ARnegative PC-3 cells. (E) There was no effect of baicalein on the growth of AR-negative DU145 cells. Data represent mean \pm SD of three independent experiments with three replicates in each experiment. 


\section{Mechanism dissection how Baicalein can suppress AR transactivation}

To dissect the mechanism how baicalein can suppress AR transactivation, we first examined its effect on AR expression, and results from Western blot analysis revealed that $2.5 \mu \mathrm{M}$ baicalein had little effect on the AR protein expression in the $\mathrm{LNCaP}$ and CWR22Rv1 cells in the presence of $1 \mathrm{nM}$ or $10 \mathrm{nM}$ DHT (Figure 5A-5B). In contrast, $2.5 \mu \mathrm{M}$ baicalein suppressed the DHT-induced PSA protein expressions (Figure 5A-5B).
A LNCaP $10 \mathrm{nM}$ DHT

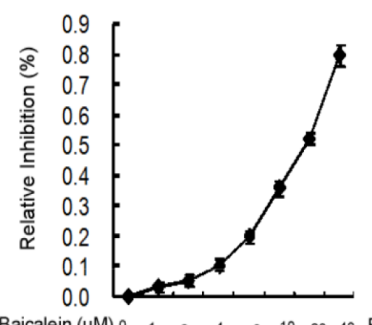

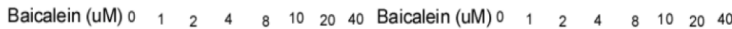
$\mathrm{LNCaP}$

B

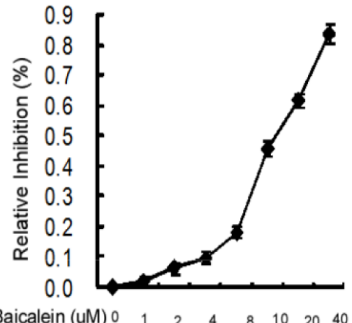

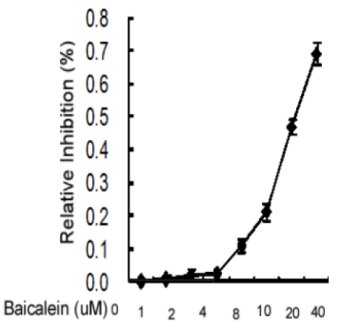

CWR22Rv1

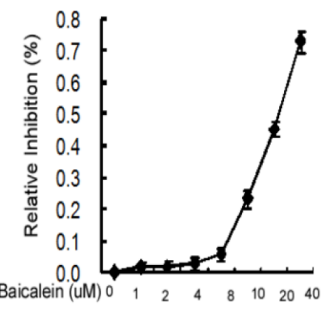

C C4-2 $10 \mathrm{nM} \mathrm{DHT}$ C4-2

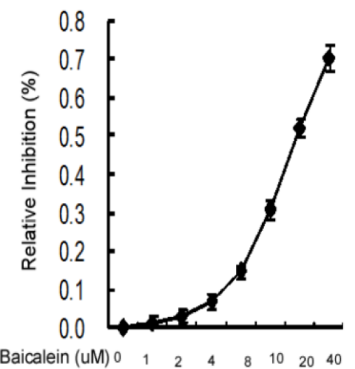

$\begin{array}{llllllllll}\text { Baicalein (UM) } & 1 & 2 & 4 & 8 & 10 & 20 & 40 & \text { Ba }\end{array}$

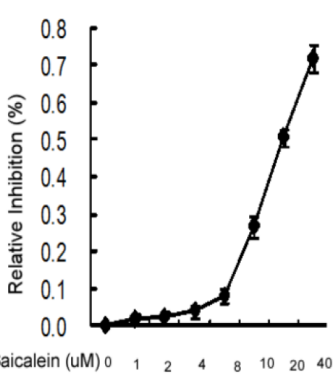

D

PC-3 10 nM DHT

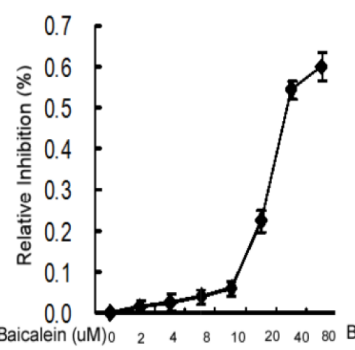

PC-3

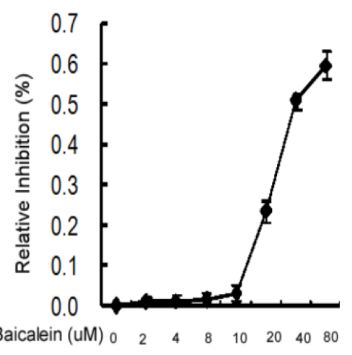

E

DU145 10 nM DHT

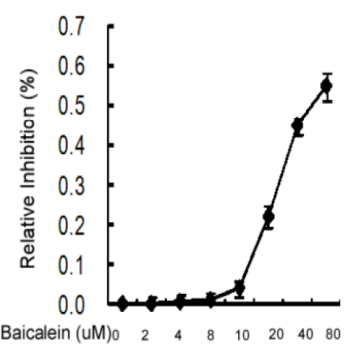

DU145

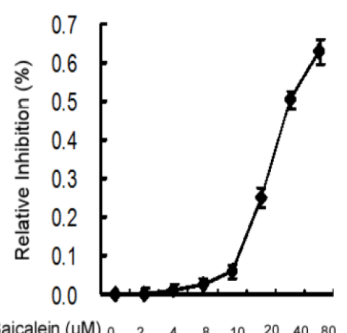

$\mathbf{F}$

\begin{tabular}{|c|c|c|}
\hline Cell & $\mathrm{IC}_{50}(\mu \mathrm{M})(1 \mathrm{nMDHT})$ & $\mathrm{IC}_{50}(\mu \mathrm{M})$ \\
\hline LNCaP & $8.8 \pm 1.4$ & $6.2 \pm 1.3$ \\
\hline CWR22Rv1 & $21.8 \pm 2.5$ & $21.3+2.5$ \\
\hline C4-2 & $16.8 \pm 2.0$ & $15.2+2.0$ \\
\hline PC-3 & $27.8 \pm 3.0$ & $27.3 \pm 3.0$ \\
\hline DU145 & $35.6 \pm 3.5$ & $33.8 \pm 3.5$ \\
\hline
\end{tabular}

Figure 3: IC50 of Baicalein in different prostate cancer cells. We determined the cell half-inhibition (IC50) of Baicalein in LNCAP, CWR22rv1, C4-2, PC-3, and DU145 cells. Cells were seeded on 24-well plates in media with 10\%FBS for 24 hrs. Media were then refreshed to media with $10 \%$ CS-FBS for another $24 \mathrm{hrs}$, and cells were treated with serial concentrations of baicalein with or without $10 \mathrm{nM}$ DHT for $48 \mathrm{hrs}$. Cell growth and $\mathrm{IC}_{50}$ value were determined by MTT assay. Half-inhibition of baicalein is shown in Figure 3A-3E. Data represent mean $\pm \mathrm{SD}$ of two independent experiments with three replicates in each experiment. 
A

LNCaP

PSA Expression

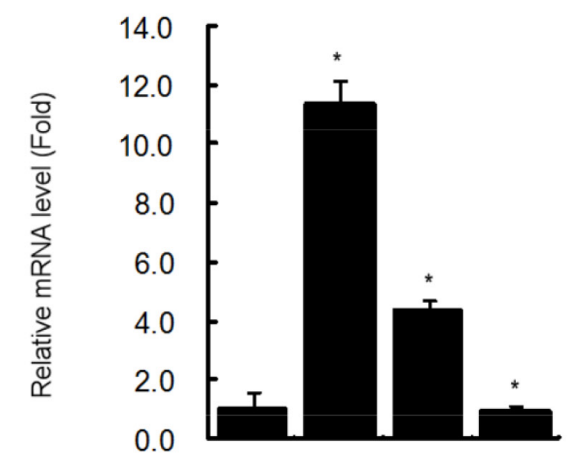

$\mathrm{DHT}(1 \mathrm{nM})$

Baicalein $(2.5 \mathrm{uM})$ - $\quad-\quad+\quad+$

B $\quad$ LNCaP

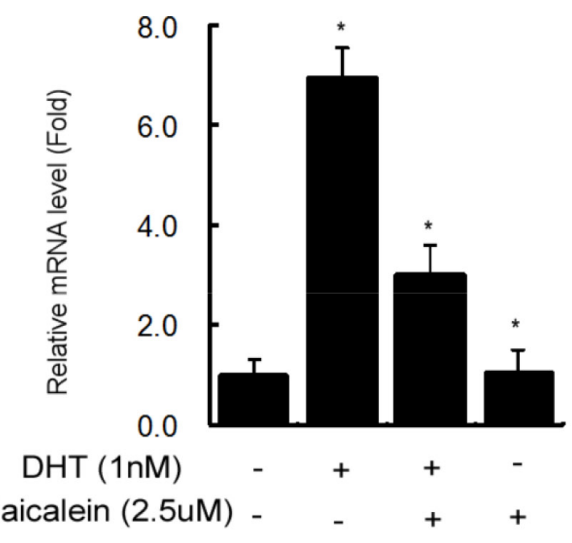

C LnCaP

TMEPA1 Expression

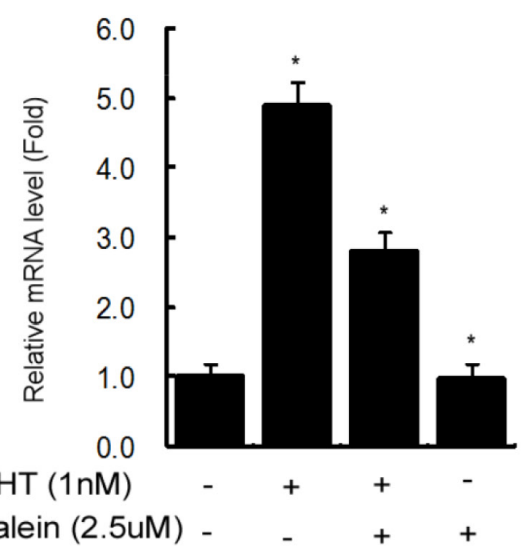

D

\section{CWR22Rv1}

PSA Expression

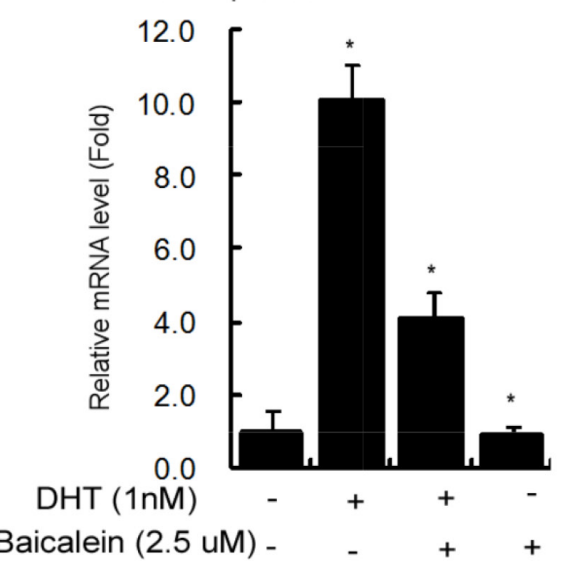

E

CWR22Rv1

TMPRSS2 Expression

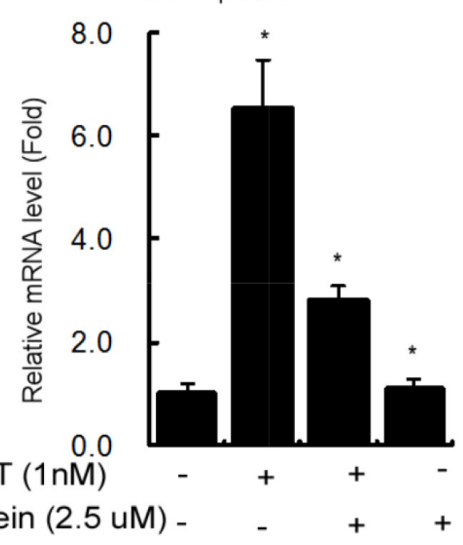

$\mathbf{F}$

CWR22Rv1

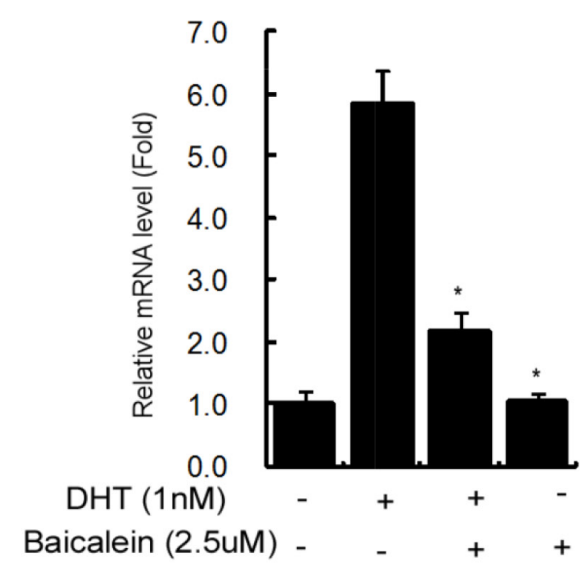

Figure 4: Baicalein Inhibits the AR target gene expression in LNCaP and CWR22Rv1 cells. Cells were treated with dimethyl sulphoxide or baicalein $(5 \mu \mathrm{M})$ in the absence or presence of $1 \mathrm{nM}$ DHT for $24 \mathrm{hrs}$. We used real-time Q-PCR to analyze the mRNA expressions of AR target genes, PSA, TMPRSS2, and TMEPA1, in LNCaP and CWR22Rv1 cells. The respective mRNA level of these genes in each treatment group was displayed as fold changes compared to the untreated group. Data are shown as the mean $\pm \mathrm{SD}$ of three independent experiments with triplicates in each experiment. 


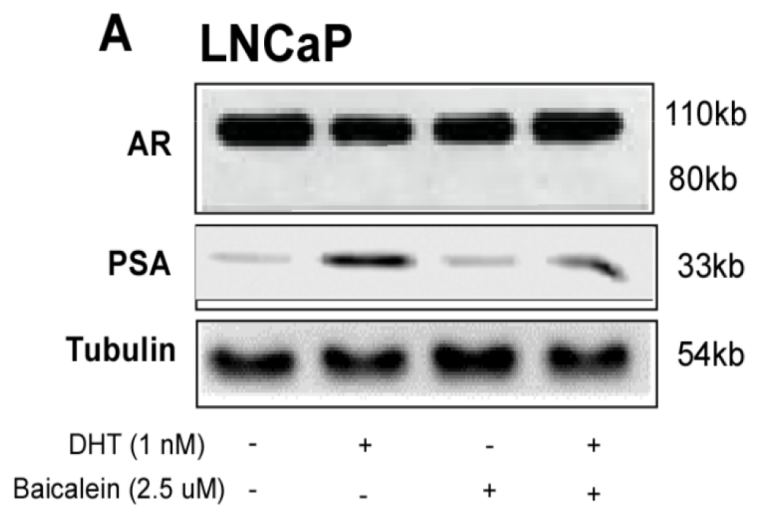

B CWR22Rv1

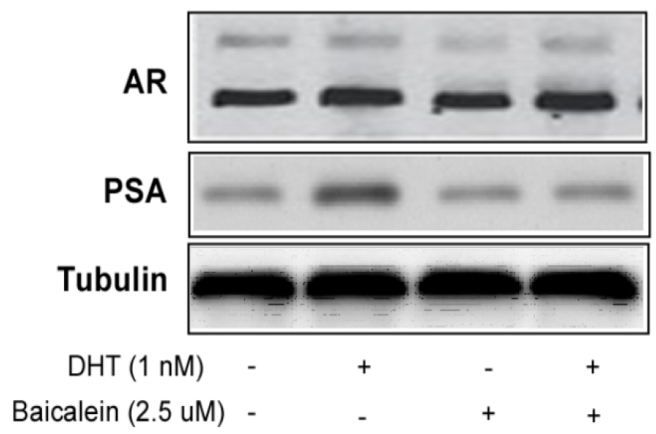

C LNCaP AR Expression

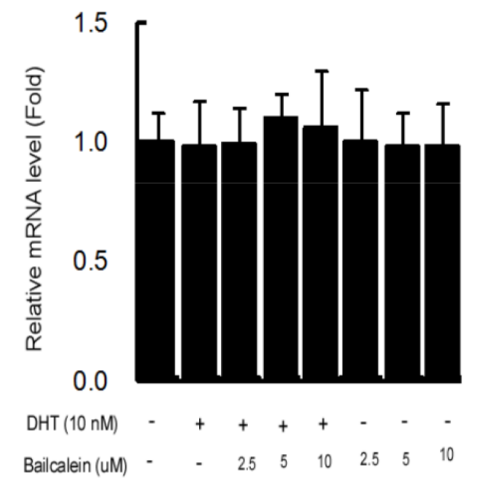

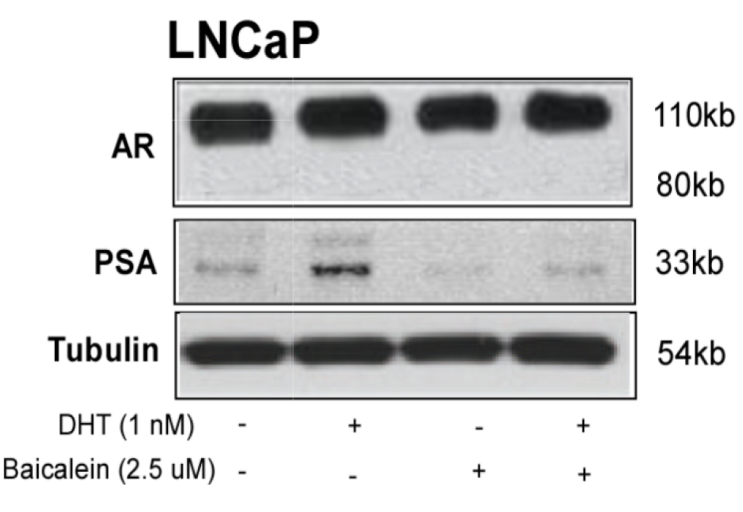

CWR22Rv1

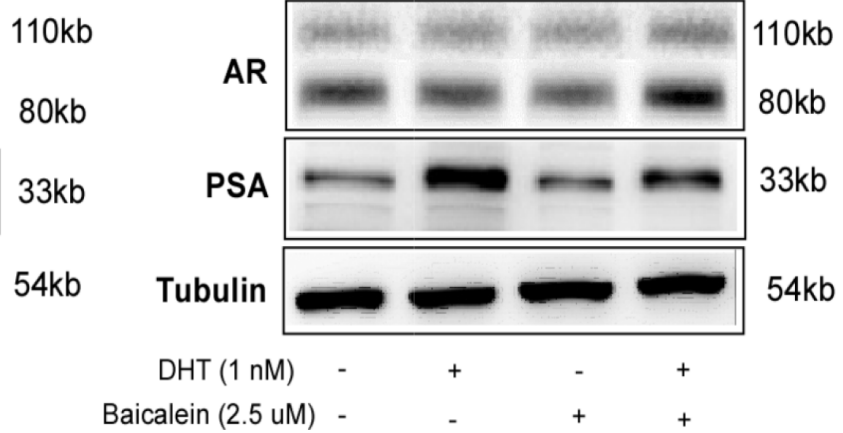

D

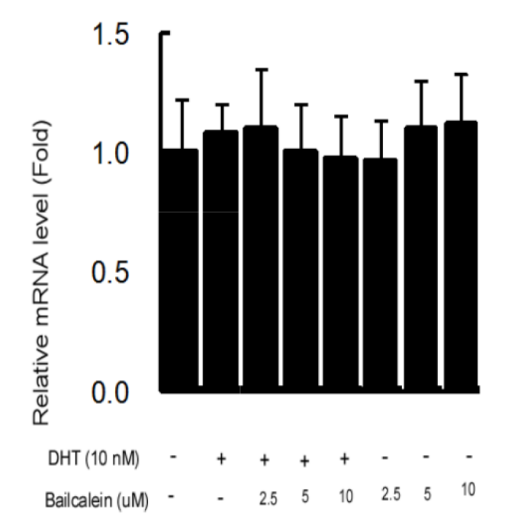

Figure 5: Baicalein inhibited AR transactivation is not via changing AR protein expression or stability. (A and B) Western blot analyses of PSA and AR levels in control and baicalein treated LNCaP or CWR22Rv1 cells in the absence or presence of DHT. Fifty $\mu \mathrm{g}$ of total protein from cells was applied onto a 10\% sodium dodecylsulfate-polyacrylamide gel and subjected to electrophoresis followed by Western blot using anti-AR, anti-PSA antibodies, and anti-tubulin antibodies. The values below the figures represent change in density of the bands normalized to $\alpha$-tubulin. Representative graphs from two independent experiments were shown. (C and $\mathbf{D})$ Baicalein does not affect AR gene expression mRNA levels in LNCaP and CWR22Rv1 cells. Cells were treated with dimethyl sulphoxide or various concentrations of Baicalein in the absence or presence of $1 \mathrm{nM}$ DHT for $24 \mathrm{hrs}$. We used real-time Q-PCR to analyze the AR mRNA expressions in LNCaP and CWR22Rv1 cells. Data are shown as the mean $\pm \mathrm{SD}$ of three independent experiments with triplicates in each experiment. 
We then studied its effect on the AR N-terminal and C-terminal (N-C) interaction that may play key role for AR functions [38, 39], and results from the mammalian 2-hybrid interaction assay in cells transfected with GAL4RE-Luc, GAL4-DBD fused-AR LBD (GAL4-AR LBD), and VP16 fused AR (VP16-AR) revealed that DHT could stimulate the AR N-C interaction, and baicalein could suppress AR N-C interaction in a dose-dependent manner (Figure 6A).

In addition to the AR dimerization, results from mammalian 2-hybrid assay also revealed that baicalein, like HF, could suppress the DHT-induced interaction of AR and its coactivator ARA70 [40] (Figure 6B).

Together, results from Figure 6A-6B suggest baicalein may suppress the AR transactivation via inhibiting the AR N/C dimerization and AR-coactivator interaction.

\section{DISCUSSION}

Traditional Chinese Medicine has been used increasingly as complementary medicine in cancer care [41]. Studying potential value of herbal medicines in clinical care has been encouraged by the World Health Organization's Traditional Medicines Strategy [42].

Flavonoids are a subclass of polyphenolic compounds that have been widely used for thousands of years in Oriental medicine due to their anti-

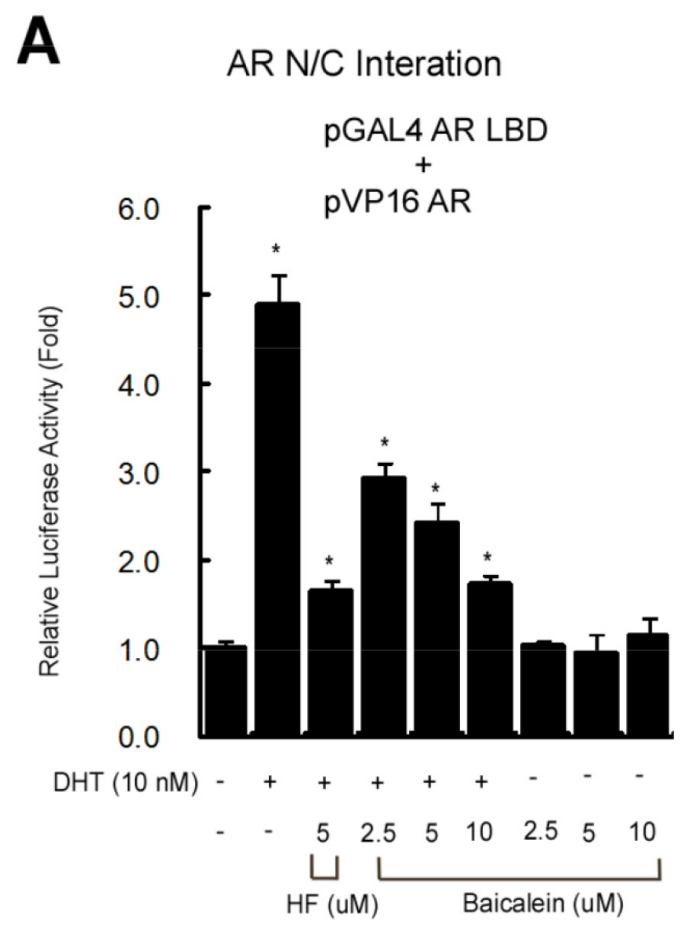

inflammatory, anti-oxidants and anti-microbial effects [43-45]. Recently, flavonoids have been demonstrated to exhibit antitumor effects in various types of cancer [46-48].

Despite the effectiveness of ADT and antiandrogen treatment strategies to delay the progression of PCa, many patients still develop the CRPC and thus there is an urgent need for alternative therapeutic targets to AR [49]. Most CRPC continues to be dependent on transcriptionally active AR for cell proliferation and survival, and it can be activated by several non-androgens factors in the castration androgen environment, suggesting in addition to use antiandrogens to reduce or prevent androgens binding to AR, targeting AR with other factors might present another approach to further suppress these CRPC [50]. Using baicalein to suppress DHT-induced AR transactivation via altering the AR N/C dimerization and AR-coactivator interaction is one of such approaches.

Recent studies indicated ADT with newly developed antiandrogen Enzalutamide might induce the castration resistance via inducing the AR splicing variant ARv7 [51-53]. Since all current antiandrogens failed to suppress ARv7 transactivation due to lack of the androgen-binding-domain, it will be interesting to see if baicalein can also suppress the interaction between ARv7 and AR.

B

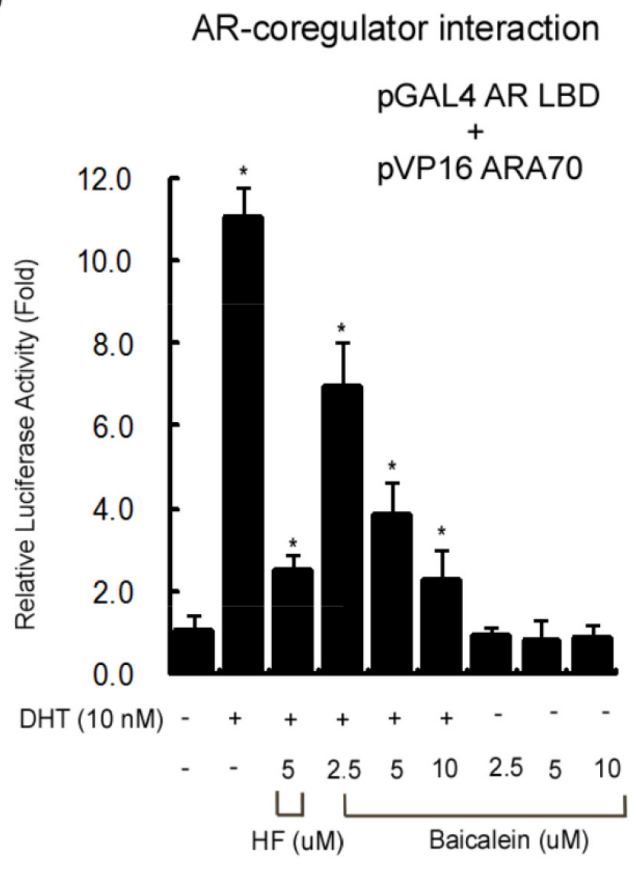

Figure 6: (A) Baicalein inhibits the AR N-C dimerization using mammalian 2-hybrid interaction assay. (B) Baicalein inhibits the interaction of AR and AR coregulator using a mammalian 2-hybrid assay. Data are shown as the mean $\pm \mathrm{SD}$ of three independent experiments with triplicates in each experiment. 


\section{MATERIALS AND METHODS}

\section{Reagents}

Commercial compounds and reagents include $5 \alpha$-dihydrotestosterone (DHT), dexamethasone (DEX), RU486, progesterone, hydroxflutamide (HF), 17ß-estradiol (E2), ICI 182,780 (ICI), methanol, dimethyl sulphoxide (DMSO), chloroform $\left(\mathrm{CHCl}_{3}\right)$, and [3-(4,5Dimethylthiazol-2-yl)-5-(3-carboxyme-thoxyphenyl)-2(4-ulfophenyl)-2H-tetrazolium] (MTT) were purchased from Sigma-Aldrich (St Louis, MO, USA) and stored at $-20^{\circ} \mathrm{C}$ in the dark. All other chemicals and solvents used in this study were of reagent grade or high performance liquid chromatography (HPLC) grade.

\section{Plant extracts preparation}

Fresh whole plants of Scutellaria baicalensis Georgi were purchased from a Chinese medicinal herb market in Jiangsu. Whole air-dried roots of Scutellaria baicalensis Georgi $(500 \mathrm{~g})$ were extracted with $70 \%$ ethanol at effluent temperature for three hrs twice. The solvent was evaporated to obtain crude extract $(49.8 \mathrm{~g})$, which was applied to the silica gel column chromatography, eluted by n-Hexane- Ethyl acetate mixture and petroleum etherEthyl acetate as mobile phases to obtain different fractions, based on the TLC pattern. Baicalein $(28 \mathrm{mg}$ ) was separated and purified under silica gel column chromatography with a solvent system of petroleum- Ethyl acetate mixture, and identified by comparison of NMR and MS spectral data with reference values [27, 28]. The stock solution of baicalein for incubation with cells was prepared in dimethyl sulfoxide and further diluted in culture medium. Final concentration of DMSO in the medium was $0.1 \%$ (to avoid its interference with cell viability). $\mathrm{H}^{1} \mathrm{NMR}$ : $(\delta$, ppm, DMSO-d $\left.\mathrm{d}_{6}, 400 \mathrm{MHz}\right): 12.57(2,1 \mathrm{H}),, 7.82-7.79(\mathrm{~m}, 2 \mathrm{H})$, $7.49(\mathrm{~d}, 1 \mathrm{H}, \mathrm{J}=15.2 \mathrm{~Hz}), 6.64(\mathrm{~d}, 1 \mathrm{H}, \mathrm{J}=15.2 \mathrm{~Hz}), 3.08(\mathrm{~m}$, $2 \mathrm{H}), 2.26(\mathrm{~s}, 3 \mathrm{H}), 1.72(\mathrm{~m}, 2 \mathrm{H}), 1.62(\mathrm{~m}, 2 \mathrm{H}), 1.27$ (s, 6H).

\section{Cell culture}

Cells were cultured at $5 \% \mathrm{CO}_{2}$ and $37^{\circ} \mathrm{C}$. $\mathrm{LNCaP}$ is an androgen-responsive and androgen dependent-human PCa cell line with a mutant AR (T877A); CWR22Rv1 is an androgen-responsive but androgen-independent human $\mathrm{PCa}$ cell line, which expresses endogenous AR; C4-2 cell line, is androgen-independent, has increased sensitivity to low levels of androgens; DU145 and PC-3 are androgenindependent human $\mathrm{PCa}$ cell lines that lack expression of AR. LNCaP, CWR22Rv1, C4-2, PC-3, and DU145 cell lines were maintained in RPMI-1640 medium containing $10 \%$ fetal bovine serum (FBS) and antibiotics (100 units/ $\mathrm{mL}$ penicillin, $100 \mu \mathrm{g} / \mathrm{mL}$ streptomycin).

HEK 293 cell line was generated by transformation of human embryonic kidney cell cultures, and maintained in
Dulbecco's modified Eagle's medium (Life Technologies) supplemented with $10 \%$ FBS and the above antibiotics.

\section{Plasmids}

The plasmids used were pSG5AR, full-length cDNA of wild-type human AR, MMTV-Luc (MMTV) a luciferase reporter plasmid, pSG5 progesterone receptor (pSG5PR), pSG5 glucocorticoid receptor (pSG5 GR), PIRES-flag-ARt877a, pSG5, pSG5AR(N-DBD), pcDNA3.1-ER $\alpha$, pGL3 (ERE) -Luc, pRL-TK pCMXVP16-ARA70, Gal4-AR-LBD, and Gal4-RE-Luc, all of which were constructed as described [29-32].

\section{Luciferase assays}

Luciferase activity, transfections, and reporter gene assays, were performed by using Lipofectamin 2000 (Invitrogen) according to the manufacturer's protocol. HEK 293 cells, lacking functional AR or ER $\alpha$, were transfected with wild-type AR or ER $\alpha$ expression plasmid and reporter gene. Briefly, $2 \times 10^{4}$ HEK 293 cells were plated on 24well dishes with $10 \%$ charcoal stripped (CS)-FBS DMEM medium for $24 \mathrm{hrs}$, medium was refreshed, and cells were transfected with pSG5-AR, pSG5-PR, pSG5-GR (for AR, PR, or GR transfections, respectively), MMTV-Luc, and pRL-TK-Luc, or with cDNA3.1-ER $\alpha$, pGL3 (ERE) ${ }_{3}$-Luc, and pRL-TK-Luc for ER $\alpha$ transfections for $24 \mathrm{hrs}$. After transfection, the medium was refreshed to $10 \%$ CS-FBS medium and cells treated with various concentrations of baicalein in the presence or absence of $1 \mathrm{nM} \mathrm{DHT}$ and/or $5 \mu \mathrm{M} \mathrm{HF}$ for $24 \mathrm{hrs}$ for AR transfections, and treated with a serial concentrations of baicalein or $10 \mu \mathrm{M}$ anti-estrogen (ICI 182,780) in the absence or presence of $10 \mathrm{nM} \mathrm{E} 2$ for 24 hrs for ER transfections. For the PR and GR reporter activity assay, $10 \mathrm{nM}$ progesterone, or DEX were added, respectively. To inhibit the progesterone-PR or DEX-GR activities, $10 \mu \mathrm{M}$ RU486 was added.

Briefly, $4 \times 10^{4}$ LNCaP cells or CWR22Rv1 cells were plated on 24-well dishes with 10\% CS-FBS RPMI1640 medium for $24 \mathrm{hrs}$, medium was refreshed and cells transfected with MMTV-ARE-Luc and pRL-TK-Luc for 24 hrs. After transfection, the medium was changed to $10 \%$ CS-FBS medium for treatment with various concentrations of baicalein in the presence or absence of $1 \mathrm{nM} \mathrm{DHT}$ and/ or $5 \mu \mathrm{M} \mathrm{HF}$ for $24 \mathrm{hrs}$. These cells were then harvested and assayed for luciferase activity using the Dual Luciferase Assay System. Data were expressed as relative luciferase activity normalized to the internal Renilla luciferase control.

For the mammalian 2-hybrid assay to determine the AR N-C interaction and AR-AR coregulator interaction, HEK 293 cells were plated on 24-well dishes with $10 \%$ CS-FBS DMEM medium for $24 \mathrm{hrs}$. Cells were transfected with pGal4-RE-Luc reporter plasmid, pGal4ARDBD-LBD (AR DNA binding domain and ligand binding domain), pCMX-VP16-AR or pCMX-VP16- 
ARA70 plasmids as indicated in the figure. After $24 \mathrm{hrs}$ transfection, the medium was refreshed to $10 \% \mathrm{CS}-\mathrm{FBS}$ medium and cells were treated with $1 \mathrm{nM} \mathrm{DHT}$ and/or baicalein for an additional 24 hrs. tk-RL luciferase was co-transfected as the internal control. Cells were then harvested for the dual luciferase assay (Promega, WI).

\section{RT-PCR and real-time PCR}

Total RNA was extracted from PCa cells using Trizol (Invitrogen). Reverse transcription was performed using the Superscript first-stand synthesis kit (Invitrogen). Quantitative real-time PCR analyses using the comparative CT method were performed on an ABI PRISM 7700 Sequence Detector System using the SYBR Green PCR Master Mix kit (Perkin Elmer, Applied Biosystems, Wellesley, MA, USA) according to the manufacturer's instructions. After an initial incubation at $50^{\circ} \mathrm{C}$ for $2 \mathrm{~min}$ and $10 \mathrm{~min}$ at $95^{\circ} \mathrm{C}$, amplification was performed for 40 cycles at $95^{\circ} \mathrm{C}$ for $20 \mathrm{~s}, 65^{\circ} \mathrm{C}$ for $20 \mathrm{~s}$, and $72^{\circ} \mathrm{C}$ for $30 \mathrm{~s}$. Specific primer pairs were determined with the PrimerExpress program (Applied Biosystems). The PSA primer pairs were 5'-AGG CCT TCC CTG TAC ACC AA-3' and 5'-GTC TTG GCC TGG TCA TTT CC-3'. The TMPRSS2 primer pairs were 5'-GTA CAC TGT TTC CAT GTT ATG-3' and 5'-AAT AAG AAG GAG TCA TTT GAG-3'. The TMEPA1 primer pairs were 5'-CCT TCT CTT CCC CTT TCC ATC TCC-3' and 5'-GTC CCG CCA ACC CCA AAT CTA TCT-3'. The hAR primer pairs were 5'-AAG GAT GGA AGT GCA GTT AG-3' and 5'-GT CCA CCG GGT TCT CCA GCT-3'. The normalization control used was $\beta$-actin, and the primers used were 5'-TCA CCC ACA CTG TGC CCC ATC TAC GA-3' and 5'-CAG CGG AAC CGC TCA TTG CCA ATG G-3'.

\section{Western blot analysis}

$2.5 \times 10^{6}$ cells (per 100-mm dish) were washed with 1x PBS and scraped into a lysis buffer. Protein concentrations were measured with the BCA protein reagent (Pierce Chemical, Rockford, IL). Approximately $50 \mu \mathrm{g}$ of protein/lane were loaded and run on a $10 \%$ polyacrylamide gel with a Tris/glycine running buffer system and then transferred onto a polyvinylidene difluoride membrane. The blots were probed with primary anti-AR (N-20), anti-PSA (C-19) antibodies with dilutions of 1:500 to $1: 1,000$ and incubated at room temperature for $2 \mathrm{hrs}$. The secondary antibody [rabbit anti-goat IgG, 1:5,000 dilution (Santa Cruz Biotechnology) or rabbit antimouse IgG, 1:5,000 dilution (Pierce Chemical, Rockford, IL)] was used at room temperature for $1 \mathrm{hr}$. Immunoblot analysis was performed with horseradish peroxidaseconjugated anti-rabbit or anti-mouse IgG antibodies using enhanced chemiluminescence Western blotting detection reagents (Amersham Biosciences). The quantification of
Western blotting results was done by Image Lab statistic software (Bio-red).

\section{Cell growth assay in vitro}

To determine cell growth, $2.0 \times 10^{4} \mathrm{LNCaP}$ cells, $1.5 \times 10^{4} \mathrm{CWR} 22 \mathrm{RV} 1$ cells, $6.0 \times 10^{3} \mathrm{C} 4-2$ cells, $5.0 \times 10^{3}$ PC -3 cells, $5.0 \times 10^{3}$ DU145 cells were plated in triplicate in 24-well culture plates. Cell medium was replenished and cell growth was determined by MTT assay (Sigma) and direct cell count. Serum-free medium containing MTT $(0.5 \mu \mathrm{g} / \mathrm{ml})$ was added into each well. After two hrs incubation at $37^{\circ} \mathrm{C}$ all crystals had solubilized and the optical density of the solution was determined spectrophotometrically at $570 \mathrm{~nm}$ [33-34].

\section{Cytotoxicity assay (the $\mathrm{IC}_{50}$ value determination) in vitro}

Cytotoxicity assay was performed according to the protocol in our laboratory [35]. To determine the $\mathrm{IC}_{50}$ value, $1.0 \times 10^{6} \mathrm{LNCaP}$ cells, 5.0 $\times 10^{5} \mathrm{CWR} 22 \mathrm{RV} 1$ cells, $6.0 \times 10^{4} \mathrm{C} 4-2$ cells, $5.0 \times 10^{4}$ DU145 cells, and $5.0 \times 10^{4} \mathrm{PC}-3$ cells were plated in triplicate in $5 \%$ CS-FBS RPMI medium in 24-well culture plates. The cells were incubated with serial concentrations of baicalein for 2 days and cell viability was determined in triplicate by MTT assay. Baicalein + medium only (no cells) were included as controls. Baicalein treated cells were compared to untreated cell control wells. $\mathrm{IC}_{50}$ values were analyzed with the program CompuSyn (Developer).

\section{Statistics}

Data are presented as the means \pm SDs for the indicated number of separate experiments. The statistical significance of differences between two groups of data were analyzed by paired t-test and P-values $<0.05$ were considered significant.

\section{CONCLUSION}

In conclusion, the results of the present study demonstrated that baicalein, a natural compound isolated from Scutellaria baicalensis Georgi extract, is a novel potential AR signaling inhibitor, which can block AR regulated gene expression and cell growth in androgensensitive cells and in CRPC cells. The inhibitory effects of baicalein are due to its interference with the AR N-C dimerization and AR-coregulator complex formation. Our data also indicated that baicalein could inhibit the E2 or Adiol-induced AR transactivation in the absence of androgens. These results suggest that baicalein may represent a promising anti-AR compound to better suppress the CRPC. 


\section{Abbreviations}

$\mathrm{AR}$, androgen receptor; $\mathrm{PCa}$, prostate cancer; RT$\mathrm{PCR}$, reverse transcription polymerase chain reaction; FBS, fetal bovine serum; ADT, androgen deprivation therapy; MTT, 3-(4,5-dimethylthiazol-2-yl)-2,5diphenyltetrazolium bromide; CRPC, castration-resistant prostate cancer; DHT,5 $\alpha$-dihydrotestosterone; DEX, dexamethasone; HF, hydroxflutamide ; E2, 17ß-estradiol; DMSO, dimethyl sulphoxide.

\section{Author contributions}

Qiulu Chen: designed most experiments; Yalin Liu: help to assay and maintain cell lines; Defeng $\mathrm{Xu}$ and Xingqiao Wen supervise entire project.

\section{CONFLICTS OF INTEREST}

The authors have no conflicts of interests to declare.

\section{FUNDING}

This work was supported in part by the Jiangsu Province science and technology, SME, innovation fund project (Grant No. BC2014026), National Natural Science Foundation of China (81372767), the Planned Science and Technology Project of Guangdong Province (2013B021800183, 2014A020212063), and Clinical Research Program of Southern Medical University of China (LY2016Y058). Research foundation of Shenzhen Hospital of Southern Medical University (PT2016LC04).

\section{REFERENCES}

1. Siegel R, Jemal A, Miller K. Cancer Statistics, 2010, CA. Cancer J Clin. 2015; 66:5-29.

2. Prensner JR, Rubin MA, Wei JT, Chinnaiyan AM. Beyond PSA: the next generation of prostate cancer biomarkers. Sci Transl Med. 2012; 28;4:127rv3.

3. Huggins $\mathrm{C}$, Hodges CV. Studies on prostatic cancer. I. The effect of castration, of estrogen and of androgen injection on serum phosphatases in metastatic carcinoma of the prostate. Cancer Res. 1941; 1:293-297.

4. Molina A, Belldegrun A. Novel therapeutic strategies for castration resistant prostate cancer: inhibition of persistent androgen production and androgen receptor mediated signaling. J Urol. 2011; 185:787-794.

5. $\mathrm{Pu} \mathrm{Y}, \mathrm{Xu} \mathrm{M}$, Liang $\mathrm{Y}$, Yang $\mathrm{K}$, Guo Y, Yang X, Fu Y. Androgen receptor antagonists compromise $\mathrm{T}$ cell response against prostate cancer leading to early tumor relapse. Sci Transl Med. 2016; 8:333ra47.

6. Hoang DT, Iczkowski KA, Kilari D, See W, Nevalainen MT. Androgen receptor-dependent and -independent mechanisms driving prostate cancer progression:
Opportunities for therapeutic targeting from multiple angles. Oncotarget. 2017; 8:3724-3745. https://doi.org/10.18632/ oncotarget. 12554.

7. Suzuki H, Hinotsu S, Akaza H, Fujii Y, Kawakami S, Kihara K, Akakura K, Suzuki M, Kitamura T, Homma Y, Mizokami A. Hormonal therapy for prostate cancer: Current topics and future perspectives. Int J Urol. 2010; 17:302-313.

8. Joensuu T, Joensuu G, Kairemo K, Kiljunen T, Riener M, Aaltonen A, Ala-Opas M, Kangasmäki A, Alanko T, Taipale L, Hervonen P, Bützow A, Virgolini I, Hemminki A. Multimodal primary treatment of metastatic prostate cancer with androgen deprivation and radiation. Anticancer Res. 2016; 36:6439-6447.

9. Schweizer MT, Antonarakis ES, Wang H, Ajiboye AS, Spitz A, Cao H, Luo J, Haffner MC, Yegnasubramanian S, Carducci MA, Eisenberger MA, Isaacs JT, Denmeade SR. Effect of bipolar androgen therapy for asymptomatic men with castration-resistant prostate cancer: results from a pilot clinical study. Sci Transl Med. 2015; 7:269ra2.

10. Ricci F, Buzzatti G, Rubagotti A, Boccardo F. Safety of antiandrogen therapy for treating prostate cancer. Expert Opin. Drug Saf. 2015; 13:1483-1499.

11. Koochekpour S. Androgen receptor signaling and mutations in prostate cancer. Asian J Androl. 2010; 12:639-657.

12. Ketola K, Viitala M, Kohonen P, Fey V, Culig Z, Kallioniemi O, Iljin K. High-throughput cell-based compound screen identifies pinosylvin methyl ether and tanshinone IIA as inhibitors of castration-resistant prostate cancer. J Mol Biochem. 2016; 5:12-22.

13. Miura Y, Oyama M, Iguchi K, Ito T, Baba M, Shikama Y, Usui S, Hirano K, Iinuma M, Mikamo H. Anti-androgenic activity of icarisid II from epimedium herb in prostate cancer LNCaP cells. J Nutr Sci Vitaminol (Tokyo). 2015; 61:201-4.

14. Li X, Yokoyama NN, Zhang S, Ding L, Liu HM, Lilly MB, Mercola D, Zi X. Flavokawain A induces deNEDDylation and Skp2 degradation leading to inhibition of tumorigenesis and cancer progression in the TRAMP transgenic mouse model. Oncotarget. 2015; 6:41809-24. https://doi. org/10.18632/oncotarget.6166.

15. LeJeune TM, Tsui HY, Parsons LB, Miller GE, Whitted C, Lynch KE, Ramsauer RE, Patel JU, Wyatt JE, Street DS, Adams CB, McPherson B, Tsui HM, et al. Mechanism of action of two flavone isomers targeting cancer cells with varying cell differentiation status. PLoS One. 2015; 10:e0142928.

16. Ma X, Yan W, Dai Z, Gao X, Ma Y, Xu Q, Jiang J, Zhang $\mathrm{S}$. Baicalein suppresses metastasis of breast cancer cells by inhibiting EMT via downregulation of SATB1 and Wnt/ $\beta$ catenin pathway. Drug Des Devel Ther. 2016; 10:1419-41.

17. Vinayagam $\mathrm{R}, \mathrm{Xu} \mathrm{B}$. Antidiabetic properties of dietary flavonoids: a cellular mechanism review, Nutr Metab (Lond). 2015; 12:60. https://doi.org/10.1186/s. 
18. Patwardhan RS, Sharma D, Thoh M, Checker R, Sandur SK. Baicalein exhibits anti-inflammatory effects via inhibition of NF- $\kappa \mathrm{B}$ transactivation. Biochem Pharmacol. 2016; 108:75-89.

19. Zhao F, Fu L, Yang W, Dong Y, Yang J, Sun S, Hou Y. Cardioprotective effects of baicalein on heart failure via modulation of $\mathrm{Ca}(2+)$ handling proteins in vivo and in vitro. Life Sci. 2016; 145:213-23.

20. Zhang Y, Shan L, Hua Y, Wang D, Zeng H, Liu R, Zhang W, $\mathrm{Hu} \mathrm{Z}$. Baicalein selectively induces apoptosis in activated lymphocytes and ameliorates concanavalin a-induced hepatitis in mice. PLoS One. 2013; 8:e69592.

21. Liu A, Wang W, Fang H, Yang Y, Jiang X, Liu S, Hu J, Hu Q, Dahmen U, Dirsch O. Baicalein protects against polymicrobial sepsis-induced liver injury via inhibition of inflammation and apoptosis in mice. Eur J Pharmacol. 2015; 748:45-53.

22. Shang D, Li Z, Zhu Z, Chen H, Zhao L, Wang X, Chen Y. Baicalein suppresses $17-\beta$-estradiol-induced migration, adhesion and invasion of breast cancer cells via the $G$ protein-coupled receptor 30 signaling pathway. Oncol Rep. 2015; 33:2077-85.

23. Liang RR, Zhang S, Qi JA, Wang ZD, Li J, Liu PJ, Huang C, Le XF, Yang J, Li ZF. Preferential inhibition of hepatocellular carcinoma by the flavonoid Baicalein through blocking MEK-ERK signaling. Int J Oncol. 2012; 41:969-78.

24. Liu X, Liu S, Chen J, He L, Meng X, Liu S. Baicalein suppresses the proliferation of acute T-lymphoblastic leukemia Jurkat cells by inhibiting the Wnt/ $\beta$-catenin signaling. Ann Hematol. 2016; 95:1787-93.

25. Liu A, Huang L, Fan H, Fang H, Yang Y, Liu S, Hu J, Hu Q, Dirsch O, Dahmen U. Baicalein pretreatment protects against liver ischemia/reperfusion injury via inhibition of NF- $\kappa \mathrm{B}$ pathway in mice. Int Immunopharmacol. 2015; 24:72-9.

26. Kim DH, Hossain MA, Kang YJ, Jang JY, Lee YJ, Im E, Yoon JH, Kim HS, Chung HY, Kim ND. Baicalein, an active component of Scutellaria baicalensis Georgi, induces apoptosis in human colon cancer cells and prevents AOM/ DSS-induced colon cancer in mice. Int J Oncol. 2013; 43:1652-8.

27. Sinha R, Joshi A, Joshi U, Srivastava S, Govil G. Localization and interaction of hydroxyflavones with lipid bilayer model membranes: a study using DSC and multinuclear NMR. Eur. J Med. Chem., 2014; 80:285-294.

28. Wang S; Chen C, Lo C, Feng J, Lin H, Chang P, Yang L, Chen L, Liu Y, Kuo C, Wu J. Synthesis and biological evaluation of novel 7-O-lipophilic substituted baicalein derivatives as potential anticancer agents. Med. Chem. Comm, 2015; 6:1864-1873.

29. Yeh S, Lin HK, Kang HY, Thin T, Lin M, Chang C. From HER2/Neu signal cascade to androgen receptor and its coactivators: a novel pathway by induction of androgen target genes through MAP kinase in prostate cancer cells. PNAS. 1999; 96:5458-5463.

30. Xu DF, Lin T, Li S, Da J, Wen X, Ding J, Chang C, Yeh S. Cryptotanshinone suppresses androgen receptor-mediated growth in androgen dependent and castration resistant prostate cancer cells. Cancer Lett. 2012; 316:11-22.

31. Yeh S, Hu YC, Rahman M, Lin HK, Hsu CL, Ting HJ, Kang HY, Chang C. Increase of androgen-induced cell death and androgen receptor transactivation by BRCA1 in prostate cancer cells. PNAS. 2000; 97:11256-11261.

32. Chen M, Ni J, Zhang Y, Muyan M, Yeh S. ERAP75 functions as a coactivator to enhance estrogen receptor $\alpha$ transactivation in prostate stromal cells. Prostate. 2008; 68:1273-1282.

33. Chen M, Ni J, Chang HC, Lin CY, Muyan M, Yeh S. CCDC62/ERAP75 functions as a coactivator to enhance estrogen receptor beta-mediated transactivation and target gene expression in prostate cancer cells. Carcinogenesis. 2009; 30:841-850.

34. Xu DF, Lin T, Li S, Zhang J, Yin M, Yeh S, Chang C. The selective inhibitory effect of a synthetic tanshinone derivative on prostate cancer cells. Prostate. 2012; 72:803-16.

35. Ni J, Pang ST, Yeh S. Differential retention of $\alpha$-vitamin $\mathrm{E}$ is correlated with its transporter gene expression and Growth Inhibition Efficacy in Prostate Cancer Cells. The Prostate. 2007; 67:463-471.

36. Chang HC, Miyamoto H, Marwah P, Lardy H, Yeh S, Huang KE, Chang C. Suppression of Delta(5)-androstenediolinduced androgen receptor transactivation by selective steroids in human prostate cancer cells. PNAS. 1999; 96:11173-7.

37. Sisecioglu M, Gulcin I, Cankaya M, Atasever A, Ozdemir $\mathrm{H}$. The effects of norepinephrine on lactoperoxidase enzyme (LPO). Sci Res Essays. 2010; 5:1351-1356.

38. Hsu CL, Chen YL, Ting HJ, Lin WJ, Yang Z, Zhang Y, Wang L, Wu CT, Chang HC, Yeh S, Pimplikar SW, Chang C. Androgen receptor (AR) $\mathrm{NH} 2-$ and $\mathrm{COOH}$-terminal interactions result in the differential influences on the AR-mediated transactivation and cell growth, molecular endocrinology.2005; 19:350-361.

39. He B, Kemppainen JA, Voegel JJ, Gronemeyer H, Wilson WM. Activation function 2 in the human androgen receptor ligand binding domain mediates interdomain communication with the NH(2)-terminal domain. J Biol Chem 1999; 274:37219-37225.

40. Yeh S, Chang C. Cloning and characterization of a specific coactivator, ARA70, for the androgen receptor in human prostate cells. PNAS. 1996; 93:5517-21.

41. de Oliveira JS, Pinto ME, Santana LA, Pinto AS, di Lenardo D, Vasconcelos DF. Biological effects of medicinal plants on induced periodontitis: a systematic review. Int J Dent. 2016; 2016:3719879. 
42. Ruiz GG, Nelson E, Kozin AF, Turner TC, Waters RF, Langland JO. A lack of bioactive predictability for marker compounds commonly used for herbal medicine standardization. PLoS One. 2016; 11:e0159857.

43. Chen H, Pu J, Liu D, Yu W, Shao Y, Yang G, Xiang Z, He $\mathrm{N}$. Anti-inflammatory and antinociceptive properties of flavonoids from the fruits of black mulberry (Morus nigra L.). PLoS One. 2016; 11:e153080.

44. Adhami VM, Mukhtar H. Anti-oxidants from green tea and pomegranate for chemoprevention of prostate cancer. Mol Biotechnol. 2007; 37:52-7.

45. Boudouda HB, Zeghib A, Karioti A, Bilia AR, Öztürk M, Aouni M, Kabouche A, Kabouche Z. Antibacterial, antioxidant, anti-cholinesterase potential and flavonol glycosides of Biscutella raphanifolia (Brassicaceae). Pak J Pharm Sci. 2015; 28:153-8.

46. Tsai $\mathrm{PH}$, Cheng $\mathrm{CH}$, Lin $\mathrm{CY}$, Huang YT, Lee LT, Kandaswami CC, Lin YC, Lee KP, Hung CC, Hwang JJ, Ke FC, Chang GD, Lee MT. Dietary flavonoids luteolin and quercetin suppressed cancer stem cell properties and metastatic potential of isolated prostate cancer cells. Anticancer Res. 2016; 36:6367-6380.

47. Wang G, Wang JJ, Du L, Fei L, To ST. Inhibitory kinetics and mechanism of flavonoids extracted from cotinus coggygria scop. Against glioblastoma cancer. Nutr Cancer. 2016; 68:1357-1368.

48. Amararathna M, Johnston MR, Rupasinghe HP. Plant polyphenols as chemopreventive agents for lung cancer. Int J Mol Sci. 2016.
49. Ingersoll MA, Lyons AS, Muniyan S, D’Cunha N, Robinson T, Hoelting K, Dwyer JG, Bu XR, Batra SK, Lin MF. Novel imidazopyridine derivatives possess anti-tumor effect on human castration-resistant prostate cancer cells. PLoS One. 2015; 10:e131811.

50. Watsona PA, Chena YF, Balbasa MD, Wongvipat J, Socci ND, Viale A, Kim K, Sawyers CL. Constitutively active androgen receptor splice variants expressed in castrationresistant prostate cancer require full-length androgen receptor. PNAS. 2010; 107:16759-16765.

51. Imamura Y, Tien AH, Pan J, Leung JK, Banuelos CA, Jian K, Wang J, Mawji NR, Fernandez JG, Lin KS, Andersen RJ, Sadar MD. An imaging agent to detect androgen receptor and its active splice variants in prostate cancer. JCI Insight. 2016; $1: \mathrm{e} 87850$.

52. Sakamoto S, McCann RO, Dhir R, Kyprianou N. Talin1 promotes tumor invasion and metastasis via focal adhesion signaling and anoikis resistance. Cancer Res. 2010; 70:1885-1895

53. Saylor PJ, Lee RJ, Arora KS, Deshpande V, Hu R, Olivier K, Meneely E, Rivera MN, Ting DT, Wu CL, Miyamoto DT. Branched chain RNA in situ hybridization for androgen receptor splice variant $\mathrm{AR}-\mathrm{V} 7$ as a prognostic biomarker for metastatic castration-sensitive prostate cancer. Clin Cancer Res. 2017; 23:363-369. 